Three Perspectives on Religious Education and Education for Citizenship in English Schools, 1934-1944: Cyril Norwood, Ernest Simon and William Temple

\author{
Dr R. J. K. Freathy \\ Lecturer in History of Education
}

\author{
School of Education and Lifelong Learning \\ University of Exeter \\ Heavitree Road \\ Exeter \\ EX1 2LU
}




\title{
Three Perspectives on Religious Education and Education for \\ Citizenship in English Schools, 1934-1944: Cyril Norwood, Ernest Simon and William Temple
}

\begin{abstract}
In recent years, in English schools, various linkages between Religious Education and Citizenship have been identified or proposed. Yet neither education for citizenship, nor its relationship with religious education, is new. Evidence for this is provided by an analysis of the public discourse pertaining to these areas, which took place between 1934 and 1944, with a focus on three influential participants: Cyril Norwood, Ernest Simon and William Temple. This paper highlights the extent to which (i) religious education was conceived as a form of education for citizenship and (ii) Christian educationists precluded secular and pedagogically progressive education for citizenship from developing in English schools. This helps to explain why Religious Instruction and worship became compulsory components of school provision in England and why education for citizenship took so long to gain a firm foothold in the curriculum.
\end{abstract}

\section{Key words}

Religious Education and Citizenship 


\section{Three Perspectives on Religious Education and Education for \\ Citizenship in English Schools, 1934-1944: Cyril Norwood, Ernest Simon and William Temple}

\section{Introduction}

In English and Welsh state-maintained schools Religious Education (RE) is a statutory curriculum subject for all pupils (except those withdrawn by their parents). In 2002, Citizenship became a statutory part of the National Curriculum (Qualifications and Curriculum Authority (QCA), 1999) at key stages three and four (11-16 year olds) (QCA, 2000a), and since 2000, primary schools (5-11 year olds) have had non-statutory guidance for Personal, Social and Health Education and Citizenship (QCA, 2000b). Various linkages between RE and Citizenship have occurred through the QCA's management structures, the publication of a Citizenship and RE Scheme of Work (Department for Education and Skills, 2006), RE Agreed Syllabuses (e.g. Devon County Council, 2001), curriculum materials (e.g. Gearon, 2003), in-service teacher training (e.g. 'How to Build an Effective Partnership Between RE and Citizenship', 2001. Standards for Education Ltd), conferences (e.g. 'Citizens of the Future', 2003, University of East Anglia), an RE with Citizenship Postgraduate Certificate in Education (Edge Hill College), and the publication of 248 job advertisements which combined RE and 
Citizenship in the Times Educational Supplement (February 2001-May 2006). ${ }^{1}$ This evidences widespread acceptance of the relationship between RE and Citizenship whether this is as curricular competitors or companions. Yet this relationship is not new. It is part of a historical continuum which this paper seeks to illuminate for the first time. It does so by analysing the public discourse pertaining to religious education and education for citizenship in English schools during the decade prior to the 1944 Education Act. It highlights the extent to which religious education was understood as a form of education for citizenship and the extent to which Christian educationists prevented secular and pedagogically progressive forms of education for citizenship from developing. Thereby, it helps to explain why Religious Instruction and worship became compulsory components of school provision in England and why education for citizenship took so long to gain a firm foothold in the curriculum. This is achieved by focusing on three of the most influential participants in the discourse: Cyril Norwood, Ernest Simon and William Temple.

\section{Arnoldian traditions}

It is possible to interpret all forms of English education relating to social and moral responsibilities, community involvement and political knowledge in the early $20^{\text {th }}$ century as 'education for citizenship'. Sometimes it was undertaken by means of explicit and direct teaching 
through a discrete subject (e.g. Civics) or through other subjects (e.g. History) (Kerr, 1999, p. 4). Marsden (2001) calls this approach 'education about citizenship' because it focused on subject matter. Another approach, which he calls 'education in or through citizenship', prioritised the learning of skills and values through participation. In elementary schools, this often consisted of explicit and direct provision, including militaristic and imperialistic activities (Heater, 2001, p. 118). In secondary schools, it was associated with implicit and indirect public school traditions that took place within a whole school Christian ethos. This latter, more popular, provision was associated with Thomas Arnold (1795-1842; Headmaster of Rugby School, 1827-42). For him, the aim of education is to inculcate religious and moral principles, gentlemanly conduct and intellectual ability (Copley, 2000, p. 32). He called for religion to rise above being a subject of teaching and instead become a way of living through which pupils learn to know and love God and goodness (Bates, 1976, p. 36). Arnold was determined to produce gentlemen who were manly-minded, conscious of duty, morally thoughtful and good (Copley, 2002, pp. 60, 120).

Arnold's ideas pervaded the 19th and early 20th century English public school system, which prepared the upper class for the privileges and duties of leadership by associating Christian education with citizenship and character training. Products of this system included the 
establishment figures who took centre-stage in the story of religious education and education for citizenship in the interwar years. Many of them fulfilled their leadership role by persuading the state sector of education to accept a version of the public school tradition which conceived of schools as religious communities in which nondenominational Christianity underpins educational order and discipline (Bates, 1976, pp. 113, 119). One of the most famous exponents of this tradition was Cyril Norwood.

\section{Cyril Norwood}

Cyril Norwood (1875-1956) was Senior Classics Master at Leeds Grammar School (1901-06), Headmaster of Bristol Grammar School (1906-16) and Master of Marlborough College (1916-26). In 1917, he also became a member, later chairman (1921-46), of the new Secondary Schools Examinations Council. From 1926 until 1934, he was Headmaster of Harrow from which position he defended the public schools from critics who claimed they were undemocratic, they expected boys to absorb Christianity, and they ignored modern trends, such as co-education, day-schooling, examinations and vocational training (Tyerman, 2000, p. 454; McCulloch and McCaig, 2002). In response, Norwood published The English Tradition of Education (1929), which propagated an educational philosophy based upon the ideals of knighthood, chivalry and the English gentleman (p. 19). It 
emphasised the ability of public schools to educate for leadership by selecting the social elite and training their characters in an ethos permeated by English culture, Christian ethics, spiritual values and community spirit (McCulloch, 2002, pp. 42, 49-50). It was a conservative form of education for citizenship which aimed to preserve the social and international order in which all members fulfilled preordained roles and shared the same civic values. Norwood was confident that an adapted version of this Platonic tradition should inspire the state education system. Consequently, he became the most famous celebrant of the 'English tradition of education' which he believed should evolve to meet valid criticisms (McCulloch, 2006).

Norwood would not change the liberal Protestantism which was 'the most important element in the ideal of a great school' and that which, he argued, underpinned Britain's predominant world position (Norwood, 1929, p. 21). He had no faith in secularity and he held that secular and progressive education undermines social cohesion and national identity (Bates, 1976, pp. 114, 188, 192; McCulloch and McCaig, 2002, pp. 243-5). For him, religion was a means of re-affirming the national, cultural, ethnic and class identity of pupils and he called for a Protestant revival to perpetuate social, moral and political values, to heal the weakness of the churches and to maintain the social order. He argued that religion should not be taught in the abstract through a 
curriculum subject, but 'caught' through devotional, academic, practical and pastoral activities. It was a version of the Arnoldian idea of a Christian school in which pupils absorb the absolute values of truth, beauty and goodness which provide the spiritual foundation of

social life (Norwood, 1929, p.22; Bates, 1976, pp. 184-6, 192-4; Michell, 1985, pp. 81, 240-3, 281; Tyerman, 2000, pp. 453-4, 457; McCulloch, 2002, p. 57).

Norwood's philosophy influenced, and cohered with, Board of Education policy which reflected the increasingly conservative nature of educational discourse during the interwar years. This was due to the buckling of the economic order, unemployment, the rise of totalitarianism abroad, declining trust in the League of Nations, disarmament and collective security, and the threat of war. These factors led many educationists to support the dissemination of traditional attitudes and values by means of public school traditions. These were preferred to progressive pedagogies and curriculum innovation because they embraced those church and state rituals that helped to maintain social cohesion and national stability.

\section{Ernest Simon}

In contrast to conceptions of good citizenship which were based on the religious, racial or geographic inheritance associated with British 
national identity, left-wing liberals and social progressives in the interwar years championed a definition of citizenship which promoted active membership of the national community and the assertion of political rights and social and moral responsibilities (Myers, 1999, pp. 320-3). It incorporated a modernist belief in the socially cohesive power of a secular patriotism which is accessible, rational, active and committed to parliamentary government, political pluralism and humane values. Ernest Simon (1879-1960) drew out its educational implications.

Simon was a Mancunian industrialist whose 'humanist agnosticism' led him to define his religion as the desire to leave the world a better place by doing good to others. In multiple diary entries, sometimes entitled 'My religion', he analysed his qualities, defects, achievements and future (Stocks, 1963, pp. 2-3, 18, 20-1, 78). This secular ethical concern led him into public service as a member of Manchester City Council (1912-23) and Liberal Member of Parliament for Withington (1923-4, 1929-31) (Jones, 2006). By the time he received his knighthood (1932), he had become concerned by the nation's economy, the rise of Fascism and anti-Semitism, and the widespread loss of confidence in parliamentary government (Stocks, 1963, pp. 91-4; Whitmarsh, 1972, pp. 28, 35). Such concerns led him and Eva Hubback (1886-1949, Principal of Morley College) to publish a pamphlet entitled Education 
for Citizenship (1934) and to establish the Association for Education in Citizenship (AEC) to discuss and disseminate theories and practices regarding training for citizenship (Simon and Hubback, 1935, p. 2; Whitmarsh, 1972, pp. 94-5).

In Training for Citizenship (1935, pp. 2, 9-16), Simon and Hubback stated that the complexity of contemporary political and economic problems and the recent loss of faith in progress meant that it was now essential for schools to provide a training in citizenship 'by which is meant training in the moral qualities necessary for the citizens of a democracy, the encouragement of clear thinking in everyday affairs and the acquisition of that knowledge of the modern world usually given by means of courses in history, geography, economics, citizenship and public affairs'. This aim was predicated on a liberal, democratic and secular version of English citizenship (Myers, 1999, p. 325). Although the founder members of the AEC acknowledged the influence of religion upon a citizen's moral qualities, they also claimed that each individual has a duty to help their fellows and to relieve suffering, regardless of their beliefs about ultimate reality (Simon and Hubback, 1935, pp. 20-1, 31). For Simon, it is the philosophical desire to do what is right, to know the truth and to desire beauty for its own sake, rather than Christianity or Humanism, which can produce a peaceful, just and efficient democratic state (Simon, 1937, pp. 6, 10-11). 
Simon's conception of education for citizenship was 'progressive' in that it was to be taught through innovative curriculum subjects and practical pedagogies. This was because he rejected the idea that pupils can transfer what they have learned from a school's corporate life and general education to the rights and responsibilities of citizenship in the wider community. Instead, he called for direct and specific training in citizenship which would entail the objective study of social, economic and political problems through subjects like Political Science and Economics (Simon and Hubback, 1935, pp. 20, 44; Whitmarsh, 1972, pp. 45-7; Wong, 1991, pp. 51-52). He also advocated participatory training as was found in newly established progressive independent schools. These provided more democratic structures, wider curricula, and practical, creative and social activities, such as the community service projects undertaken by the Pioneers at Bryanston (Happold, et al., c1937; Whitmarsh, 1972, p. 81; McCulloch, 2002, pp. 51, 54). Overall, the AEC acted as a pressure group which sought to replace Christian and traditional forms of indirect education for citizenship with secular and pedagogically progressive forms of direct education for citizenship. 


\section{Professional conservatism}

The AEC aimed to influence the Board of Education via Sir Will Spens' Consultative Committee (Whitmarsh, 1974, p. 135), but the Consultative Committee was formed by and working for the professionally conservative Board of Education which had come under the influence of Sir Cyril Norwood (knighted in 1938). Despite being an AEC member, Norwood believed that political matters are beyond the comprehension of children and that indirect education for citizenship is best. Consequently, the 'Spens Report' (Board of Education, 1938, pp. xxxvii-xxxviii, 160,163,189) stated that only the foundations of political studies can be laid before the age of 16 by bringing the curriculum into closer contact with the practical affairs of life and the national ethos, and by recognising the influence upon pupils of the school community and teachers (Whitmarsh, 1972, pp. 60-1). By contrast, the report stated that pupils cannot be counted as properly educated unless they have been made aware of 'a religious interpretation of life' (Board of Education, 1938, p. 208). Consequently, it commended school worship, specialist Scripture teaching, Local Education Authority (LEA) Agreed Syllabuses, the Institute of Christian Education (est. 1935) and teacher training for Religious Instruction (Board of Education, 1934). In addition, it called for religious education to deal more directly with the application of Christian principles to the problems of adult life (Board of Education, 1938, pp. 170-1, 206-17). 
The AEC was not politically powerful enough to influence the Consultative Committee and its attempts to influence the Board of Education directly were frustrated by politicians and civil servants. Moreover, education for citizenship had failed to become a practical professional matter other than 'in terms of the elaboration of the school as a benevolent hierarchical social system whose ethical values were anchored in formal religion' (Whitmarsh, 1972, p. 102). This Christian and traditional form of education for citizenship was given further support when the Board of Education appointed a sub-committee of the Secondary Schools Examinations Council, under the chairmanship Sir Cyril Norwood (President of St John's College, Oxford, 1934-46), to investigate the curricula and examinations of state secondary schools.

Although much evidence was submitted in support of new subjects like 'Citizenship', the 'Norwood Report' (Secondary School Examinations Council, 1943) stated a number of reasons why direct education for citizenship is inappropriate: (i) it is harmful to attempt to interest pupils prematurely in adult matters; (ii) the political and social sense needed to sustain a modern democracy is best taught incidentally through ordinary subjects; and (iii) pupils' characters are unconsciously trained by a school's teachers, everyday life and general spirit which should be founded on Christian values. The report maintained that 
public school traditions, including Chapel, Confirmation and Christian vocationalism, should be paradigmatic for state secondary schools. It advocated a religious programme, including weekly Religious Instruction, to ensure that schools made up for the deficiencies of homes and churches by introducing pupils to the Christian interpretation of life and ethical standard (Secondary School Examinations Council, 1943, pp. 56-9, 61, 84-9, 98-101).

For Myers (1999, pp. 323-5), the Norwood Report demonstrates how educational constructions of English citizenship and national identity became increasingly couched in explicitly Christian terms during the 1930s and 1940s, in contrast to the liberal, democratic and secular version of citizenship promoted by Ernest Simon. This was because the Board of Education and the educational establishment utilised the international crisis and the contemporary emphasis upon England's Christian tradition in forming good character to fashion policy in a conservative manner. Myers believes that Norwood was the most vocal advocate of an ethereal, spiritual and traditional sense of citizenship which was founded on religion, discipline, culture, athletics and service. Yet, the Board of Education's acceptance of Norwood's Christian and traditional form of education for citizenship in LEA schools may not have been possible without the contribution of William Temple. 


\section{William Temple}

William Temple (1881-1944) was a Lecturer at Queen's College, Oxford (1904-10), President of the Workers' Educational Association (1908-24), Headmaster of Repton School (1910-14), Priest of St. James's, Piccadilly (1914-19), Labour Party member (1918-21), Canon of Westminster Abbey (1919-21), Bishop of Manchester (1921-29), and Archbishop of York (1929-42) then Canterbury (1942-44). In addition, he became the first president of the British Council of Churches in 1942 and provided much of the motivation for the establishment of the World Council of Churches in 1948 (Hastings, 1986, pp. 304, 392; Hastings, 2004, p. 7; Kent, 1998, p. 32).

In terms of politics, Temple's Protestant patriotism first came to prominence at the Birmingham Conference on Politics, Economics and Citizenship in 1924 (Kent, 1998, pp. 23, 29). He believed that the only safe course for democracy is that it should recognise its source in Christianity and he criticised secular political ideologies for assuming that humankind has no meaning and value other than earthly citizenship (Temple, 1956, p. 7; Suggate, 1980, p. 118; Baker, 1946, pp. 219-20). He wanted a doctrinally inclusive Established Church to give expression to the spiritual, co-operative and organic national unity, which, he believed, underlay social divisions. He also argued that 
Church Establishment pertains to the state's recognition of, rather than control of, the national Church which is the agent of the community and guides its social, economic and political life (Temple, 1956, p. 65;

Grimley, 1998, pp. 47, 70, 99). In Christianity and the Social Order (1956), Temple asserted the Church's national significance by proposing a series of Christian guidelines for post-war government including 'a moderate redistribution of opportunity, wealth and political power, without which national unity would be impossible' (Kent, 1998, p. 23). His purpose was to create a Christian social order, which ensures the full development of personality through free purposeful choice, the widest and deepest fellowship and occupations undertaken as God-given vocations. It was one way in which he led the Church of England to accept that social, political and economic issues are matters of Christian concern (Baker, 1946, pp. 219-20; Hastings, 1986, pp. 179, 185; Hastings, 2004, p. 6).

In regard to education, Temple argued that all children should receive an education that is planned for their particular aptitudes and inspired by faith in God through worship. He believed that schools should develop children's personalities to their full potential within an environment which is corporate, spiritual, co-operative and concerned with giving people the power to pronounce judgment on any facts, rather than individual, intellectual, competitive and concerned simply 
to supply people with facts. For Temple, the school community itself is the great educator and all young people should be members of such a community, enjoying its support and accepting responsibility for it. $\mathrm{He}$ hoped that schools would become places of training for citizenship by the actual experience and practice of life in a community. Yet he did not believe that schools can foster both individual development and worldcitizenship without ensuring that their corporate lives are Christian and that community service is valued. These Arnoldian ideas were influenced by his father, Frederick (Headmaster of Rugby, 1857-69), and his headmaster, John Percival (Headmaster of Rugby, 1887-95) (Temple, 1956, pp. 92-3; Iremonger, 1948, pp. 60, 82-4; Suggate, 1980, p. 127; Louis, 1985, pp. 35-6).

Temple's conception of ecumenical Christian citizenship and his enthusiasm for Christian education were of central importance in relation to the negotiations leading up to the 1944 Education Act. Traditionally, the Anglican and Roman Catholic churches had obstructed state intervention in education, except in the form of subsidies for church schools, because they regarded nondenominational or secular education provided in LEA schools as a threat. However, the ecumenical movement, in which Temple was a key player, had facilitated the development of non-denominational Religious Instruction syllabuses defined by Anglicans, Nonconformists, LEAs and 
teachers. The introduction of these syllabuses into all maintained schools by some LEAs had been sufficient to persuade a number of Anglican dioceses to support the state's re-organisation of secondary education according to the Hadow Report's recommendations (Board of Education, 1926; Cruickshank, 1963, p. 125). Ecumenical forms of religious education had been professionalising under the auspices of the Institute of Christian Education whose president was William Temple (Temple, 1936). This development helped to ensure that the Board of Education and its Consultative Committee could promote Christian education for citizenship in LEA schools without fear of provoking denominational division.

Despite this, the 'Green Book' of proposals for post-war educational reform (Education after the War, 1941) caused controversy with the Anglican and Roman Catholic churches (Cruickshank, 1963, p. 145). In response, the newly appointed President of the Board of Education Richard Butler (1902-82) - sought to find a compromise which would retain the financial contribution of the churches, diminish denominational rivalry and limit the autonomy of voluntary school managers. The likelihood of reaching a compromise was heightened when William Temple was appointed Archbishop of Canterbury. He guided the Established Church to support the reformation of the education system, whilst at the same time ensuring that the Christian 
values, which he believed underpin the national community, were borne out in the fullest possible programme of religious education in LEA schools (Jeffereys, 1984, p. 420; Chadwick, 1997, p. 28; Cruickshank, 1963, p. vii). He also prevented denominational dispute by working hard for Nonconformist co-operation, supported the major non-religious reforms (e.g. the raising of the school leaving age), and mollified those who opposed church schools and religious education (Iremonger, 1948, p. 575). In the House of Lords debates regarding the White Paper, he stated that schools should develop the aptitudes and talents of individuals in such an atmosphere that these gifts will be used in public service. He also noted that it 'is only in the community of school life that it is possible for the young person fully to exercise, and so become perfect by practice in, the spirit and temper of citizenship'. For him, the overall object of the reforms was to ensure that the whole life of the nation's schools 'is conducted as part of the training, not only of citizens, but of Christian citizens' (Temple, 1943). It was a sufficiently widely held vision to be enacted in legislation.

\section{The 1944 Education Act}

The 1944 Education Act made LEAs responsible for contributing towards the spiritual, moral, mental and physical development of the community of which they serve through primary, secondary and further education. LEA schools became 'county schools' and church schools 
were divided into 'voluntary aided', 'voluntary controlled' and 'special agreement' schools, depending on the level of public funding which they received and the extent to which church managers were responsible for determining policy.

The 1944 Education Act stated that every county and voluntary school should provide a daily and, where practicable, single act of collective worship and weekly Religious Instruction for all pupils, except those withdrawn by their parents. The Act also stated that Religious Instruction in aided or special agreement schools should be controlled by the school managers, but that in county schools it should be taught according to an Agreed Syllabus. In voluntary controlled schools denominational instruction was permissible on parental request. In addition, changes were made to improve the quality of Religious Instruction: specialist provision was facilitated by the abolition of the 'Timetable' clause, which had limited Religious Instruction and worship to the beginning or end of a school session; His Majesty's Inspectors could now inspect Religious Instruction, except in aided or special agreement schools; LEAs were permitted to establish Standing Advisory Councils on Religious Education for consultation purposes; and teacher trainees could offer Religious Knowledge in the teachers' certificate examination. 
This statutory requirement for religious education was the outcome of a process by which the secular conception of English citizenship promoted by the founder members of the AEC was superseded by a professionally conservative desire to make the dominant form of communal gathering in schools and the only compulsory subject attestations of non-denominational Christianity as the national faith (Myers, 1999, pp. 323-4). Subsequently, many LEAs produced new or revised Agreed Syllabuses which embodied the desire of Christian educationists to establish a Christian social order. Middlesex County Council's Agreed Syllabus of Religious Instruction for Middlesex Schools (1948) maintained that the chief task of a school is to train pupils to become Christian citizens by presenting eternal principles relating to the family, nation-states, the world, economics and citizenship (Copley, 1997, p. 33).

One of the consequences of the 1944 Education Act was that religious education and education for citizenship remained almost synonymous and Religious Instruction and worship were the most explicit means by which citizenship was taught. At the same time, the idea that direct education for citizenship was only suitable for older adolescents provided a key argument for the statutory introduction of County Colleges in each LEA for 15-18 year olds who are not in full-time education. Although the Ministry of Education did not manage to 
finance their development, the purpose of County Colleges was to provide part-time compulsory further education to develop the various aptitudes and capacities of young people and to prepare them for the responsibilities of parenthood and citizenship. Thus, although the 1944 Education Act confirmed the failure of the AEC's attempts to introduce a secular and pedagogically progressive form of education for citizenship into schools, it was the first time that education for citizenship was specifically mentioned in an Act of Parliament.

The AEC emerged from the war with negligible public organisation, irregular sources of revenue, and no coherent outlet for its theories (Whitmarsh, 1972, p. 136). Nevertheless, it was probably as a result of the AEC's campaigns that the Ministry of Education published Pamphlet No. 16: Citizens Growing Up (1949), which was the only 'government-produced' publication on education for citizenship prior to National Curriculum Council Guidance 8: Education for Citizenship (1990). Citizens Growing Up promoted the social, spiritual and moral emphasis of the old education for citizenship tradition in contrast to the specifically political reference point of the AEC: Christianity was accepted as the basis of moral education and democracy; schools were criticised for providing occasional, extra and discrete lessons on 'Current Affairs', 'Civics' or 'Citizenship'; and the corporate life of schools was judged to be the best means of providing training in 
citizenship. It was an explicit endorsement of indirect character training and Arnoldian public school traditions. By this time, Lord (Ernest) Simon of Wythenshawe had withdrawn from the AEC to concentrate on his chairmanship of the British Broadcasting Corporation (1947-52). The AEC was finally terminated in 1957.

\section{Conclusion}

By 1944, the professionally conservative Board of Education had rejected Ernest Simon's call for the introduction of direct instruction and progressive pedagogies to teach a liberal, democratic and secular form of citizenship in English schools. The Board of Education would not endorse anything that would introduce political conflict into schools or undermine the traditional role of teachers as the exemplification of social and moral standards. It also espoused that direct instruction in citizenship is beyond the capabilities of children. Simon's supporters were not politically powerful enough to influence official policy-making and his secular campaign was also deeply out of kilter with the wider wartime view that English citizenship is founded on Christian morals and values.

This conservative construction of national identity led the Board of Education to endorse the Christian and traditional form of indirect education for citizenship which was promoted by influential Christian educationists like Cyril Norwood and Archbishop William Temple. 
Consequently, Religious Instruction and worship became compulsory components of LEA school provision on the basis that they were the most suitable means of explicitly and directly preparing children for citizenship of Christian Britain. Furthermore, it was as a result of the ecumenical movement, in which Temple was such a key player, that religious education could be interpreted as nationally cohesive rather than denominationally divisive. Therefore, it is possible to argue that Christian educationists played a central part in ensuring that education for citizenship did not gain a firm foothold in the curriculum of English schools in the mid-20 $0^{\text {th }}$ century. The majority of these Christian educationists were products of the Arnoldian public school tradition and the educational aims, pedagogical methods and curricular content which they had experienced at school were absorbed into theories of religious education which lasted without challenge until the 1960s. Since then, indirect and holistic methods of training have continued to be advocated in relation to religious education in church schools and the promotion of children's spiritual, moral, social and cultural development in all schools (Copley, 2000). Thereby, the legacy of Norwood and Temple is evident in our contemporary educational scene.

Meanwhile, the creation of a multi-faith Britain through mass immigration on the one hand, and the partial disentanglement of Christian culture from the political allegiance of UK citizenship through 
state secularisation on the other, created a context in the early $21^{\text {st }}$ century in which it was possible for a secular and pedagogically progressive form of education for citizenship to arise in community schools. The final report of Professor Bernard Crick's Advisory Group on Citizenship (1998) and the National Curriculum definition of Citizenship (QCA, 1999; 2000a; 2000b) suggest that Simon's conception of education for citizenship has triumphed in the long run over Norwood and Temple's Christian and traditional forms. This would be a reverse of the result that occurred in the 1940s. However, the evidence presented at the beginning of this paper, regarding the current relationship between RE and Citizenship, suggests that the aims, methods and content of religious education and education for citizenship have not diverged as much as Simon's successors would have expected or converged as much as Norwood and Temple's successors would have hoped.

\section{Note}

1 This statistic has been generated through a survey of job advertisements in the Times Educational Supplement. Because some advertisements may have been missed, the figure represents the minimum number. It sheds no light on internal appointments.

\section{References}


Advisory Group on Citizenship. (1998) Education for citizenship and the teaching of democracy in schools. (London: QCA).

Baker, A. E. (1946) William Temple and His Message (Harmondsworth: Penguin Books).

Bates, D. J. (1976) The Nature and Place of Religion in English State Education c1900-c1944 with Special Reference to Conceptions of the relations of Religion to Education and the development of Christian Education c1920-c1944 (Unpublished Ph.D. Thesis, University of Lancaster).

Board of Education Consultative Committee. (1926) Education of the Adolescent (London: HMSO).

Board of Education. (1934) Report of a Conference held at the Board of Education on November $30^{\text {th }}, 1933$, and March $20^{\text {th }}, 1934$, on The Provision of Improved Opportunities for Teachers to Equip themselves for giving Religious Instruction (London: HMSO).

Board of Education Consultative Committee. [1938] (Reprint 1949) Secondary Education with Special Reference to Grammar Schools and Technical High Schools (London: HMSO).

Secondary School Examinations Council. (1943) Curriculum and Examinations in Secondary Schools. (London: HMSO). Chadwick, P. (1997) Shifting Alliances: Church and State in English Education (London: Cassell). 
Copley, T. D. (1997) Teaching Religion: Fifty Years of Religious

Education in England and Wales (Exeter: University of Exeter Press).

Copley, T. D. (2000) Spiritual Development in the State School: A

Perspective on Worship and Spirituality in the Education System of

England and Wales (Exeter: University of Exeter Press).

Copley, T. (2002) Black Tom Arnold of Rugby: The Man and The Myth (London: Continuum).

Cruickshank, M. (1963) Church and State in English Education: 1870 to the Present Day. (London: Macmillan).

Devon County Council. (1992) Promoting Quality: The Agreed Syllabus for Religious Education (Exeter: Devon County Council).

Department for Education and Skills. (2006) The Standards Site. Schemes of Work. Citizenship at key stage 3. Unit 13: How do we deal with conflict?. Available online at:

http://www.standards.dfes.gov.uk/schemes2/citizenship/cit13/ (accessed 31 May 2006).

Gearon, L. (Ed). (2003) Citizenship Through Secondary Religious Education (London: Routledge Falmer)

Grimley, M. (1998) Citizenship, Community and the Church of England: Anglican Theories of the State c1926-1939 (Unpublished Ph.D. Thesis. University of Oxford). 
Happold, F. C., Hoyland, W. F., Deed, B. L., Sharp, C. H. C., Dobinson, C. H., Frampton, R. and Hahn, K. (c1937) Experiments in Practical Training for Citizenship. No. 5 (London: AEC).

Hastings, A. (1986) A History of English Christianity 1920-1985 (London: Collins).

Hastings, A. (2004) 'Temple, William (1881-1944)'. Oxford Dictionary of National Biography. Available online at: http://owww.oxforddnb.com.lib.ex.ac.uk:80/view/article/36454 (accessed 10 April 2006).

Heater, D. (2001) The history of citizenship education in England. The Curriculum Journal 12(1).

Iremonger, F. A. (1948) William Temple. Archbishop of Canterbury. His Life and Letters (London: Oxford University Press).

Jeffereys, K. (1984) R. A. Butler, The Board of Education and the 1944 Education Act. History. Vol. 69. 415-431.

Jones, B. [2004] (2006) Simon, Ernest Emil Darwin, first Baron Simon of Wythenshawe (1879-1960). Oxford Dictionary of National biography. Available online at: http://owww.oxforddnb.com.lib.ex.ac.uk:80/view/article/36095 (accessed 10 April 2006).

Kent, J. (1998) William Temple, the Church of England and British national identity. In Weight, R. and Beach, A. (Ed). (1998) The Right to 
Belong: Citizen and National Identity in Britain, 1930-1960 (London: Tauris Academic Studies).

Kerr, D. (1999) Re-examining citizenship education: the case of England (Slough: National Foundation for Education Research).

Louis, P. (1985) Anglican Attitudes to the Relationship between the church and education with particular reference to the thoughts of William Temple, Spencer Leeson, Robert Stopford and Robert Waddington (Unpublished M.Phil. Thesis, University of Manchester). McCulloch, G. (1989) The Secondary Technical School: A Usable Past? (London: Falmer Press).

McCulloch, G. [1991] (2002) Philosophers and Kings: Education for Leadership in Modern England (Cambridge: Cambridge University Press).

McCulloch, G. (2006) Cyril Norwood and the English tradition of education. Oxford Review of Education. 32(1). 55-69.

McCulloch, G. and McCaig, C. (2002) Reinventing The Past: The Case of the English Tradition of Education. British Journal of Educational Studies. 50(2). 238-253.

Marsden, B. (2001) Citizenship education: permeation or pervasion?

Some historical pointers. In Lambert, D. and Machon, L. (2001)

Citizenship Through Secondary Geography (London:

Routledge/Falmer). 
Michell, C. E. (1985) Christian Education and the Christian Nation: a study of the role envisaged for religious education in British State Schools. c1920-1965 (Unpublished M. Litt. Thesis. University of Cambridge).

Ministry of Education. (1949) Pamphlet No. 16: Citizens Growing Up (London: HMSO).

Myers, K. (1999) National Identity, citizenship and education for displacement: Spanish refugee children in Cambridge, 1937. History of Education. 28(3). 313-25.

National Curriculum Council. (1990) National Curriculum Council Guidance 8: Education for Citizenship (York: NCC).

Norwood, C. (1929) The English Tradition of Education (London: John Murray).

Qualifications and Curriculum Authority. (1999) Citizenship: The National Curriculum for England and Wales (London: QCA).

Qualifications and Curriculum Authority. (2000a) Personal, social and health education and citizenship at key stage 1 and 2 (London: QCA). Qualifications and Curriculum Authority. (2000b) Citizenship at key stage 3 and 4. (London: QCA).

Simon, E. (1937) The Faith of a Democrat. The Citizen. 4. 5-13.

Simon, E. and E. M. Hubback. (1935) Training for Citizenship (London: Oxford University Press). 
Stocks, M. (1963) Ernest Simon of Manchester (Manchester:

Manchester University Press).

Suggate, A. M. (1980) William Temple's Christian Social Ethics: A

Study in Method (Unpublished Ph.D. Thesis, University of Durham).

Temple, W. (1936) Teachers and the Need of Our Time. Religion in

Education. 3(4). 81-83.

Temple, W. [1942] (1956) Christianity and the Social Order (Harmondsworth: Penguin Books).

Temple, W. (1943) Speech to the House of Lords, $4^{\text {th }}$ August.

Parliamentary Debates, Lords, Vol. 128. Cols. 1000-4.

Tyerman, C. (2000) A History of Harrow School 1324-1991 (Oxford:

Oxford University Press).

Whitmarsh, G. (1972) Society and the School Curriculum: The Association for Education in Citizenship 1935-57 (Unpublished M.Ed. Thesis. University of Birmingham).

Whitmarsh, G. (1974) The Politics of Political Education. Journal of Curriculum Studies 6(2) 133-142.

Wong, Y. Y. J. (1991) Continuity and Change in Citizenship Education in England in the Twentieth Century (Unpublished Ph.D. Thesis. University of Liverpool). 